\title{
Pengembangan Buku Saku Pertumbuhan dan Perkembangan dengan Pengayaan Mortalitas Larva Aedes Aegypti
}

\section{A Pocket Book Development on Growth and Development Enriched with Aedes Aegypti Larval Mortality}

\author{
Gita Aprilia, Titin, Wolly Candramila* \\ Pendidikan Biologi FKIP Universitas Tanjungpura Pontianak \\ *wolly.candramila@fkip.untan.ac.id \\ diterima : 15 Januari 2021; dipublikasi : 31 Maret 2021 \\ DOI: 10.32528/bioma.v6i1.3996
}

\begin{abstract}
ABSTRAK
Penelitian ini bertujuan untuk mengembangkan buku saku dengan diperkaya informasi tentang mortalitas larva Aedes aegypti sebagai media pembelajaran pada Materi Pertumbuhan dan Perkembangan. Penelitian pengembangan ini menggunakan 3 tahap pertama dalam model 4D yaitu define (penetapan), design (perancangan), dan develop (pengembangan). Media buku saku divalidasi oleh 5 orang validator dilihat dari aspek format, isi dan bahasa yang secara keseluruhan mencakup 16 kriteria. Hasil validasi didapatkan nilai CVR dan CVI 0,99 yang memenuhi kriteria minimal untuk content validity. Dengan demikian, media buku saku yang diperkaya mortalitas larva Aedes aegypti layak digunakan sebagai media pembelajaran pada materi pertumbuhan dan perkembangan.
\end{abstract}

Kata kunci: Pengembangan, Model 4D, Buku Saku, Mortalitas, Aedes aegypti

\begin{abstract}
This study aimed to develop a pocket book enriched with Aedes aegypti larval mortality as a learning medium on Growth and Development Materials. This development research used the first 3 stages in the 4D model, namely define, design, and develop. The book media was validated by 5 validators based on 16 criteria in format, content and language aspects. The validation results obtained CVR and CVI values of 0.99 which meet the minimum criteria for Lawshe's content validity. Thus, the pocket book media enriched with the Aedes aegypti larval mortality was suitable to be a learning medium on growth and development materials.
\end{abstract}

Keywords: Development, 4D Model, Pocket Book, Mortality, Aedes aegypti 


\section{PENDAHULUAN}

Pembelajaran merupakan interaksi yang terjadi selama proses belajar antara tenaga pengajar, peserta didik, dan komponen pembelajaran dalam suatu lingkungan belajar (Pane \& Darwis Dasopang, 2017, p. 334). Proses pembelajaran memerlukan strategi pembelajaran yang tepat dan relevan dengan tujuan pembelajaran yang ingin dicapai. Strategi pembelajaran terdiri dari kerja sinergis berbagai komponen pembelajaran yang meliputi tujuan, guru, peserta didik, bahan ajar, metode, media, dan evaluasi pembelajaran (Dolong, 2016, p. 295).

Komponen pembelajaran yang harus ada dalam setiap kegiatan pembelajaran dan harus mendapat perhatian dari guru adalah media pembelajaran karena kehadirannya akan menentukan efektivitas, efisiensi, dan daya tarik peserta didik terhadap materi yang akan disampaikan (Miftah, 2013, p. 96). Media digunakan sebagai sarana penyampaian pesan berupa materi dari guru kepada peserta didik dalam proses pembelajaran (Daryanto, 2012, p. 4). Berdasarkan penelitian Rafiuddin et al. (2017, p. 147), penggunaan media oleh guru tergolong penting karena dapat mempermudah dan mempercepat pemahaman materi serta dapat meningkatkan hasil belajar pada peserta didik. Penggunaan media pembelajaran yang tepat dan bervariasi diharapkan dapat menumbuhkan minat belajar, menimbulkan interaksi langsung yang terjadi antara peserta didik dengan lingkungannya serta menumbuhkan minat peserta didik belajar mandiri sesuai kemampuannya (Tafonao, 2018, p. 108). Proses belajar mandiri dapat terwujud dengan penggunaan media yang memudahkan peserta didik belajar kapanpun dan dimanapun. Salah satu media pembelajaran yang dapat digunakan oleh peserta didik secara mandiri adalah buku saku.

Buku saku merupakan media pembelajaran yang berisikan suatu informasi, berukuran kecil, ringan, muat jika dimasukkan ke dalam saku, dan praktis untuk dibawa dan dibaca. Banyak jenis media lain yang memiliki kelebihan dan keuntungan selama penggunaannya dalam pembelajaran, penggunaan buku saku tetap dapat memberikan manfaat pada situasi dan kondisi yang mendukung, misalnya, karena berupa media cetak maka penggunaannya tidak memerlukan aliran listrik, selain itu, peserta didik dapat mengendalikan pembelajaran dengan membacanya berulang sesuai kebutuhannya. Bagi guru, kondisi kelas yang kurang kondusif misalnya karena cuaca buruk atau hujan 
lebat dapat dibantu dengan buku saku untuk penyampaian materi dengan cara dibagikan kepada kelompok-kelompok kecil dalam pembelajaran berkelompok. (Sari, Noor Linda Vitria, 2010, p. 29) penggunaan buku saku dibandingkan media lain memiliki beberapa kelebihan di antaranya berukuran kecil sehingga memudahkan untuk dibawa, dapat digunakan setiap saat, berisi informasi yang penyajiannya terfokus, mudah untuk disebarluaskan kepada peserta didik, dan tidak mudah rusak saat digunakan. Buku saku dapat digunakan dengan mudah oleh semua kalangan, penggunaannya dalam proses pembelajaran dapat berdampingan dengan media lain, serta tidak memerlukan peralatan penunjang atau peralatan khusus. Buku saku memuat materi yang penyampaiannya bisa diseragamkan, materi yang disajikan pada buku saku lebih singkat dan jelas sehingga akan menimbulkan pengalaman belajar yang menyenangkan dan menarik, serta penggunaan buku saku lebih efisien dari segi waktu dan tenaga.

Penggunaan media buku saku dapat membantu guru dan peserta didik dalam proses pembelajaran. Hasil penelitian (Pramika, 2018, p. 11) menunjukkan bahwa media buku saku yang dikembangkan untuk pembelajaran matematika ekonomi meningkatkan keaktifan dan hasil belajar mahasiswa. Pengembangan media buku saku oleh (Azadirachta \& Sumarmi, 2018, p. 111) menunjukkan bahwa buku saku dapat meningkatkan pengetahuan dan keterampilan praktik peserta didik. (Trisianawati et al., 2017, p. 229) menemukan bahwa buku saku sebagai bahan bacaan peserta didik dapat meningkatkan hasil belajar pada Materi Kalor di kelas VII SMPN 5 Monterado. (Zuhra et al., 2017, p. 138) juga mendapatkan bahwa penerapan model pembelajaran learning cycle 7E yang disertai media buku saku dapat meningkatkan hasil belajar peserta didik. (Setyono et al., 2013, p. 125) juga menyatakan bahwa penggunaan buku saku sebagai media pembelajaran fisika kelas VIII materi gaya dapat meningkatkan minat baca pada peserta didik terhadap materi yang dipelajari. Hasil-hasil penelitian tersebut menyimpulkan bahwa penggunaan buku saku tidak hanya bisa meningkatkan hasil belajar tetapi juga meningkatkan keaktifan, pengetahuan dan keterampilan praktik, karakter yang lebih baik, dan minat baca peserta didik.

Peningkatan kedalaman isi dalam materi buku saku, perlu dilakukan pengayaan dengan informasi-informasi penting misalnya berupa terapan dari konsep yang sedang diajarkan, misalnya, pada Materi Pertumbuhan dan Perkembangan di kelas XII SMA 
guru dapat menampilkan pengayaan berupa hal-hal terkait. Penelitian ini, dijabarkan proses pengembangan dan pengujian kelayakan buku saku pada Materi Pertumbuhan dan Perkembangan yang diperkaya oleh hasil pengamatan mortalitas larva dari Aedes aegypti. Buku saku ini diharapkan dapat menjadi alternatif media dalam pembelajaran Materi Pertumbuhan dan Perkembangan sekaligus menambah wawasan peserta didik terkait hasil penelitian yang disampaikan sebagai pengayaan. Proses pengembangan media yang disajikan dalam penelitian ini juga diharapkan dapat menstimulasi guru untuk menciptakan media pembelajaran yang lebih bervariasi dengan mengangkat hasilhasil penelitian lainnya untuk menambah pengetahuan dan ketertarikan peserta didik dalam pembelajaran.

\section{METODE}

Penelitian ini berbentuk deskriptif dengan model riset pengembangan (development research) yang dilakukan pada bulan Januari - Juli 2020. Pengembangan media buku saku mengacu pada tahapan Development Research dari (Thiagarajan et al., 1976, p. 5) yang menggunakan model 4D (define, design, develop, disseminate) akan tetapi pada penelitian ini dibatasi sampai pada tahap develop pengembangan.

Tahap define merupakan tahap analisis situasi yang dihadapi oleh guru, karakteristik peserta didik dan konsep yang akan dimuat pada media pembelajaran melalui wawancara dengan 3 orang guru SMA di Kota Pontianak. Wawancara yang dilakukan terkait strategi pembelajaran yang digunakan oleh guru dalam proses pembelajaran pada Materi Pertumbuhan dan Perkembangan Makhluk Hidup. Tahapan yang kedua yaitu design (perancangan), yaitu merupakan tahapan merancang media buku saku meliputi penentuan ukuran media buku saku yang digunakan yaitu $14,8 \mathrm{x}$ 10,5 cm mengacu pada (Suryanda et al., 2019, p. 199), pengembangan materi dari berbagai sumber, menyusun format dan isi buku saku yang dimodifikasi dari buku saku hasil penelitian (Windayani et al., 2018) yaitu cover, petunjuk penggunaan, kata pengantar, daftar isi, kompetensi dasar (KD), indikator pencapaian kompetensi (IPK), tujuan pembelajaran, uraian materi, rangkuman, soal-soal evaluasi, kunci jawaban, daftar pustaka, dan glosarium. Alat yang digunakan dalam pembuatan buku saku meliputi laptop, kamera, printer, serta program Microsoft Publisher dan Microsoft Word 
dalam Microsoft Office 2013. Bahan yang digunakan meliputi buku biologi kelas XII dan buku referensi karangan Soenardihardjo (2017), serta artikel penelitian.

Tahapan ketiga dalam penelitian ini yaitu development (pengembangan) merupakan tahapan di mana media buku saku yang sudah dirancang akan divalidasi untuk diperbaiki sesuai dengan kebutuhan pembelajaran. Tahapan ini, dilakukan uji kelayakan media buku saku Materi Pertumbuhan dan Perkembangan menggunakan lembar validasi hasil modifikasi dari lembar validasi media buku saku (Ami et al., 2012) dan instrumen penilaian buku teks pelajaran Badan Standar Nasional Pendidikan (BSNP, 2014). Validasi media buku saku terdiri atas 3 aspek yang meliputi aspek format, isi dan bahasa. Pengukuran dalam instrumen validasi media buku saku menggunakan skala Likert dengan jawaban dan skor pernyataan validasi yaitu sangat baik (SB) bernilai 4, baik (B) bernilai 3, kurang baik (KB) bernilai 2, dan tidak baik (TB) bernilai 1. Validasi media buku saku dilakukan oleh 5 orang validator yang terdiri dari 2 orang dosen Pendidikan Biologi FKIP Universitas Tanjungpura Pontianak dan 3 orang guru mata pelajaran Biologi kelas XII SMA di Kota Pontianak. Pemilihan ketiga sekolah di Kota Pontianak menggunakan teknik random sampling berdasarkan nilai UNBK Tahun 2018 dan diambil masing-masing satu sekolah pada peringkat atas, tengah dan bawah.

Hasil validasi media buku saku dianalisis menggunakan Content Validity Ratio (CVR) dan CVI (Content Validity Index) atau nilai rata-rata CVR secara keseluruhan (Lawshe, 1975). Buku saku valid atau layak digunakan apabila nilai CVR dan CVI memenuhi batas minimum Lawshe yaitu 0,99 untuk 5 orang validator. Media buku saku yang sudah divalidasi kemudian direvisi berdasarkan saran validator.

\section{HASIL DAN PEMBAHASAN}

Pengembangan media buku saku diawali dengan tahap define. Tahapan define merupakan tahap awal dengan menelaah hal-hal yang dibutuhkan dalam proses belajar, menganalisis tujuan serta batasan materi yang akan dikembangkan. Tahap define dilakukan melalui wawancara dengan 3 orang guru biologi SMA/MA di Kota Pontianak. Penentuan 3 sekolah dilakukan berdasarkan nilai UNBK Tahun 2018 peringkat atas (SMA A), tengah (SMA B), dan bawah (SMA C). Wawancara dilakukan 
kepada guru biologi SMA kelas XII yang mengajar pada Materi Pertumbuhan dan Pengembangan. Pertanyaan yang diberikan kepada guru terkait strategi yang digunakan dalam proses mengajar pada Materi Pertumbuhan dan Perkembangan yang meliputi model, metode, media, dan permasalahan atau kendala yang dihadapi (Tabel 1). Hasil wawancara menunjukkan bahwa model pembelajaran yang digunakan pada Materi Pertumbuhan dan Perkembangan berupa Discovery Learning dengan metode diskusi, tanya jawab, serta picture \& picture. Media yang digunakan berupa PowerPoint (2 sekolah) dan tidak menggunakan media (1 sekolah). Permasalahan/ kendala yang dihadapi dalam proses pembelajaran Materi Pertumbuhan dan Perkembangan diantaranya sarana dan prasarana yang terbatas dan hasil belajar peserta didik yang rendah.

Tabel 1. Hasil wawancara terkait model, metode, media, dan permasalah/ kendala dalam pembelajaran Materi Pertumbuhan dan Perkembangan

\begin{tabular}{|c|c|c|c|}
\hline Aspek Wawancara & SMA A & SMA B & SMA C \\
\hline \multirow[t]{2}{*}{ Model Pembelajaran } & Discovery & Discovery & Discovery \\
\hline & Learning & Learning & Learning \\
\hline Metode & Diskusi & Picture \& Picture & Diskusi dan Tanya \\
\hline Pembelajaran & Tanya Jawab & & Jawab \\
\hline Media Pembelajaran & Slide PowerPoint & Slide Power Point & - \\
\hline Permasalahan/ & - & Sarana & Hasil belajar yang \\
\hline Kendala & & prasarana & rendah \\
\hline & & terbatas & \\
\hline
\end{tabular}

Tahapan selanjutnya yaitu design. Pada tahap ini buku saku dirancang sebagai media pembelajaran pada materi pertumbuhan dan perkembangan. Secara format, ukuran buku saku sebesar 14,8 x 10,5 cm (A6) mengacu pada Suryanda dkk. (2019, p. 199) dan terdiri dari 54 halaman. Jenis kertas yang digunakan adalah glossy double side dengan berat 120 gsm. Buku saku dicetak dengan ukuran yang kecil sehingga memudahkan peserta didik untuk membawa dan menggunakannya kapanpun dan dimanapun. Jumlah halaman buku saku sebaiknya berkisar antara 50-100 halaman sehingga bisa dimuati oleh isi materi yang cukup lengkap tetapi sekaligus tidak Gita Aprilia, et al., Pengembangan Buku . . 
menyulitkan saat dibawa atau digenggam. Peserta didik yang menggunakan buku saku akan memperoleh ringkasan informasi sehingga waktu belajar lebih efisien, lantaran bentuknya yang kecil dan praktis serta susunan materi yang disajikan lebih padat dan ringkas jadi mudah dipahami. Materi pertumbuhan dan Perkembangan terdiri atas 4 konsep yaitu pertumbuhan dan perkembangan, fase-fase pertumbuhan dan perkembangan, faktor-faktor yang mempengaruhi pertumbuhan dan perkembangan, serta desain penelitian. Merancang isi materi dalam buku saku ini dipilih tentang mortalitas larva Aedes aegypti. Pemilihan topik mortalitas larva Aedes aegypti untuk dijadikan pengayaan dalam Materi Pertumbuhan dan Perkembangan adalah untuk memberikan penguatan konsep fase-fase dan faktor-faktor yang mempengaruhi pertumbuhan dan perkembangan serta memberikan contoh laporan penelitian ilmiah pada Submateri Desain Penelitian. Hasil penelitian memberikan informasi berupa penjelasan dan grafik pertumbuhan dan perkembangan, tahapan dalam proses pertumbuhan dan perkembangan serta faktor-faktor yang mempengaruhi pertumbuhan dan perkembangan. Secara isi, rancangan buku saku pada Materi Pertumbuhan dan Perkembangan diambil dari berbagai sumber terkait yang sudah disesuaikan dengan KD, indikator, dan tujuan pembelajaran. Menurut Abidin (2020, p.12), media merupakan salah satu komponen dalam sistem pembelajaran yang mempengaruhi tercapainya tujuan pembelajaran. Media berperan untuk memberikan pedoman bagi guru dalam mencapai tujuan pembelajaran dengan menjelaskan materi pembelajaran secara sistematis, serta menyajikan materi dengan menarik sehingga meningkatkan kualitas pembelajaran. Hasil penelitian pada media buku saku diharapkan dapat menjadikan proses belajar tidak sekedar hafalan melainkan berisi aplikasi nyata dari materi tersebut karena proses pembelajaran biologi dekat dengan lingkungan sehari-hari sehingga dapat meningkatkan motivasi peserta didik dalam mempelajari materi. Pengayaan informasi mortalitas larva Aedes aegypti dapat memperjelas konsep faktorfaktor yang mempengaruhi pertumbuhan dan perkembangan dengan menampilkan hasil pengujian ekstrak bengkuang secara empiris.

Langkah selanjutnya pada tahap design adalah menyusun format dan isi dari buku saku yang mengacu pada Windayani dkk. (2018). Bagian-bagian buku saku dapat dilihat pada Gambar 1 yang meliputi cover, petunjuk penggunaan, kata pengantar, 
daftar isi, kompetensi dasar (KD), indikator pencapaian kompetensi (IPK), tujuan pembelajaran, uraian materi, rangkuman, soal evaluasi, kunci jawaban, daftar pustaka, dan glosarium. Buku harus memiliki cover dengan ciri khas yang tidak dimiliki oleh desain cover buku lainnya yaitu pengangkatan tema tertentu, dalam hal ini tema yang diangkat dalam desain cover buku saku yaitu pertumbuhan dan perkembangan dengan menampilkan pula larva Aedes aegypti. Bagian cover buku saku juga menggunakan beragam kombinasi warna yang menarik perhatian peserta didik. Bagian petunjuk penggunaan sudah tertera dalam buku saku yang terdiri dari petunjuk penggunaan bagi guru dan peserta didik sehingga guru dan peserta didik dapat mempelajari cara penggunaannya dalam proses pembelajaran melalui petunjuk tersebut. Bagian kata pengantar terdapat pada halaman setelah pertunjuk penggunaan yang berisi ucapan terimakasih peneliti pada pihak-pihak yang telah membantu pembuatan media buku saku.

Bagian setelah kata pengantar adalah daftar isi yang memudahkan peserta didik dan guru menemukan halaman-halaman tertentu pada buku saku berdasarkan bagian-bagiannya, selanjutnya terdapat uraian kompetensi dasar (KD), indikator pencapaian kompetensi (IPK), dan tujuan pembelajaran, Uraian materi yang disajikan harus sesuai dengan $\mathrm{KD}$, indikator dan tujuan karena ketiga komponen tersebut memiliki fungsi masing-masing dalam proses pembelajaran yaitu KD adalah kemampuan minimal yang harus dikuasai oleh peserta didik, indikator adalah pengukuran perilaku peserta didik untuk menentukan ketercapaian KD yang menjadi acuan penilaian dalam proses pembelajaran, serta tujuan pembelajaran merupakan proses dan hasil belajar yang diharapkan dicapai oleh peserta didik. 


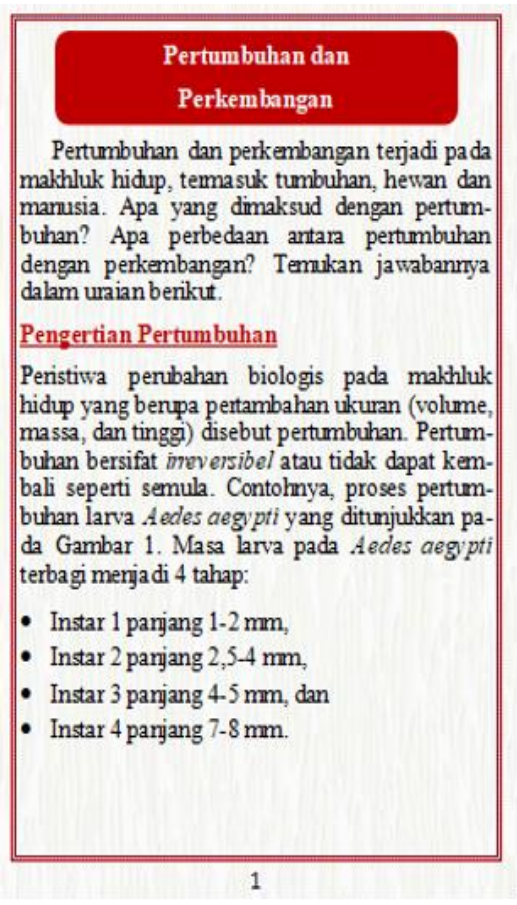

(a)

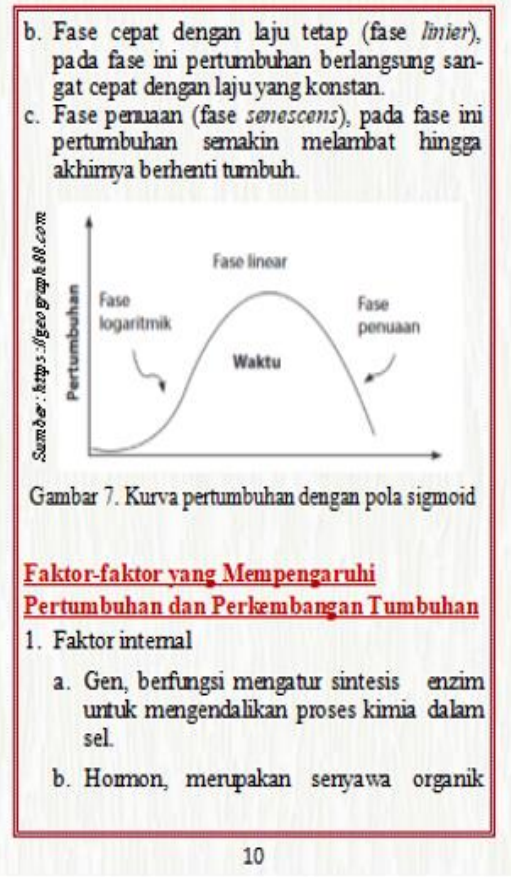

(c)

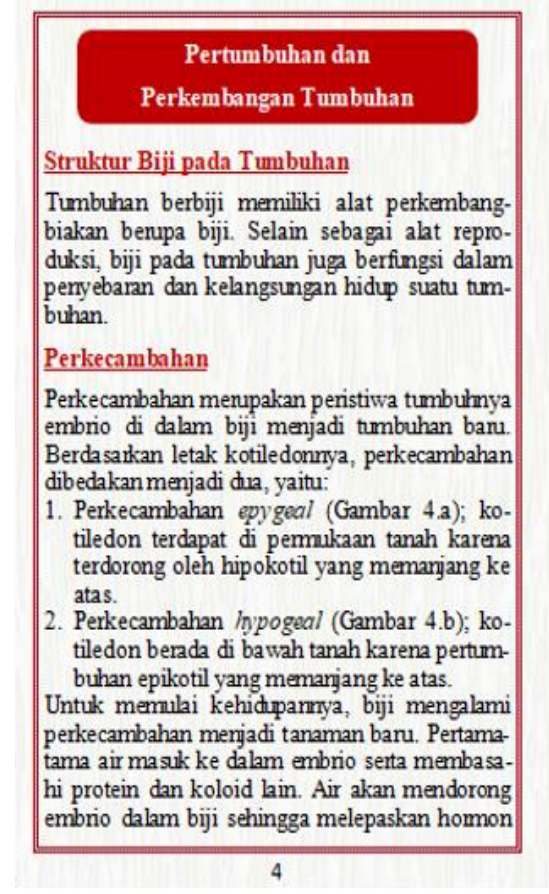

(b)

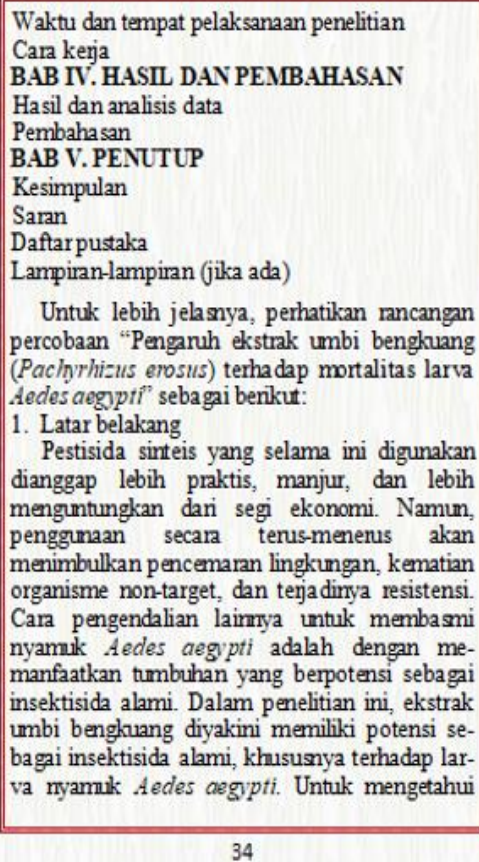
organisme non-target, dan terja dinva resistensi. Cara pengendalian lainnya untuk membasmi nyamuk Aedes aegypti adalah dengan memanfaatkan tumbuhan yang berpotensi sebagai insektisida alami. Dalam penelitian ini, ekstrak umbi bengkuang diyakini memiliki potensi sebagai insektisida alami, khususnya terhadap larva nyamuk Aedes aegypti. Untuk mengetahui

34

Gambar 1. Buku saku pertumbuhan dan perkembangan dengan pengayaan mortalitas larva Aedes aegypti 
Bagian selanjutnya yaitu uraian materi. Seluruh materi dalam buku saku pertumbuhan dan perkembangan disajikan secara sistematis dan terstruktur. Materi pelajaran harus dimulai dari bagian pendahuluan yaitu materi yang mudah terlebih dahulu agar lebih dipahami peserta didik. Buku saku, bagian pendahuluan berisi tentang konsep pertumbuhan dan perkembangan pada makhluk hidup yang terdiri dari 3 halaman. Bagian isi merupakan bagian utama yang berisi materi, dalam buku saku pertumbuhan dan perkembangan, bagian isi dilanjutkan dengan materi fase-fase pertumbuhan dan perkembangan, faktor yang mempengaruhi pertumbuhan dan perkembangan serta desain penelitian yang terdiri dari 32 halaman. Bagian penutup yang merupakan kesimpulan dari materi yang disajikan. Buku saku, terdapat rangkuman tentang materi pertumbuhan dan perkembangan yang terdiri dari 1 halaman. Pemberian rangkuman membantu peserta didik memahami pokok-pokok isi pembelajaran, seperti konsep, prosedur, atau prinsip, memperkuat ingatan peserta didik dan pendalaman dari apa yang dipelajari.

Buku saku pertumbuhan dan perkembangan juga dilengkapi dengan latihan soal, yang berfungsi untuk melihat seberapa banyak penyerapan materi oleh peserta didik (Anita et al., 2018, p. 35). Soal evaluasi pada buku saku terdiri dari 10 soal pilihan ganda yang dimuat dalam 3 halaman. Bagian setelah latihan soal adalah kunci jawaban, tujuannya agar peserta didik mengerjakan soal terlebih dahulu tanpa melihat kunci jawaban. Buku saku terdapat pula petunjuk bagi peserta didik dalam memberikan nilai sendiri pada hasil jawabannya, dan tindak lanjut kegiatan yang harus dilakukan setelah peserta didik mengetahui nilai yang diperoleh, seperti terus melakukan kegiatan belajar berikutnya bila ia berhasil dengan baik yaitu memperoleh nilai minimal 80, dan mengulang kembali mempelajari materi bila nilai yang diperoleh dibawah 80 , setelah itu, terdapat bagian daftar pustaka yang berisi rujukan yang digunakan selama penyusunan materi buku saku pertumbuhan dan perkembangan. Terakhir terdapat bagian glosarium yang dapat mengingatkan kembali peserta didik terhadap istilahistilah penting yang semula asing dengan adanya glosarium peserta didik dapat mengetahui istilah tersebut, bagian glosarium terdapat 27 istilah penting yang dimuat dalam 5 halaman. 
Tahapan yang terakhir dalam penelitian ini adalah develop/ pengembangan. Pada tahap ini, buku saku yang sudah disusun divalidasi oleh 5 orang validator yang terdiri dari 2 orang dosen dan 3 orang guru biologi SMA di Kota Pontianak. Lembar validasi buku saku terdiri dari 3 aspek dan 16 kriteria. Hasil validasi dapat dilihat pada Tabel 2.

Tabel 2. Nilai CVR dan CVI media buku saku pertumbuhan dan perkembangan dengan pengayaan mortalitas larva Aedes aegypti

\begin{tabular}{|c|c|c|}
\hline Aspek & Kriteria & CVR \\
\hline \multirow[t]{6}{*}{ Format } & 1. Kemudahan membawa buku saku & 0,99 \\
\hline & 2. Kejelasan huruf (font) pada media buku saku & 0,99 \\
\hline & 3. Kemenarikan desain cover dari buku saku & 0,99 \\
\hline & 4. Kejelasan gambar pada buku saku & 0,99 \\
\hline & 5. Kelengkapan penyajian buku saku & 0,99 \\
\hline & 6. Kelengkapan pendukung penyajian materi & 0,99 \\
\hline \multirow[t]{6}{*}{ Isi } & $\begin{array}{l}\text { 7. Kesesuaian materi dengan } \mathrm{KD} \text {, indikator dan tujuan } \\
\text { pembelajaran }\end{array}$ & 0,99 \\
\hline & 8. Keruntutan penyajian materi pada buku saku & 0,99 \\
\hline & $\begin{array}{l}\text { 9. Kelengkapan informasi yang diberikan pada buku } \\
\text { saku }\end{array}$ & 0,99 \\
\hline & 10. Kesesuaian materi dengan perkembangan ilmu & 0,99 \\
\hline & $\begin{array}{l}\text { 11. Kesesuaian materi yang disajikan dengan hukum dan } \\
\text { perundang-undangan }\end{array}$ & 0,99 \\
\hline & $\begin{array}{l}\text { 12. Kesesuaian penyajian hasil penelitian dengan tujuan } \\
\text { pembelajaran }\end{array}$ & 0,99 \\
\hline \multirow[t]{5}{*}{ Bahasa } & 13. Keterbacaan bahasa yang digunakan pada buku saku & 0,99 \\
\hline & $\begin{array}{l}\text { 14. Kesesuaian bahasa pada buku saku dengan kaidah } \\
\text { Bahasa Indonesia }\end{array}$ & 0,99 \\
\hline & 15. Konsistensi penggunaan istilah/simbol/lambang & 0,99 \\
\hline & 16. Ketepatan penulisan nama ilmiah/asing & 0,99 \\
\hline & CVI & 0,99 \\
\hline
\end{tabular}


Setelah nilai CVR pada masing-masing kriteria penilaian diperoleh, maka selanjutnya nilai CVI (Content Validity Index) dihitung untuk mendeskripsikan validitas secara keseluruhan. Hasil perhitungan CVI yang diperoleh yaitu 0,99 (Tabel 1). Nilai CVI tersebut menunjukkan bahwa semua bagian pada media buku saku sesuai dengan kriteria-kriteria yang ditentukan sehingga media buku saku dinyatakan layak digunakan sebagai media pembelajaran pada materi pertumbuhan dan perkembangan. Berdasarkan hasil uji kelayakan, pengembangan buku saku dengan model 4D menghasilkan produk yang layak digunakan dalam pembelajaran. Tahap berikutnya perlu dilakukan uji coba penggunaan buku saku dalam pembelajaran agar proses pengembangan buku saku benar-benar dapat menjadi alternatif media yang dapat dimanfaatkan guru dalam pembelajaran biologi.

\section{KESIMPULAN DAN SARAN}

Media buku saku dikembangkan menggunakan model development research dengan tahapan define, design, dan develop. Buku saku pertumbuhan dan perkembangan dengan pengayaan mortalitas larva Aedes aegypti layak digunakan sebagai media pembelajaran pada Materi Pertumbuhan dan Perkembangan kelas XII SMA/MA dengan nilai CVI sebesar 0,99 untuk 16 kriteria. Dari hasil validasi diharapkan dapat dilakukan penelitian lebih lanjut berupa uji coba penggunaan media buku saku pertumbuhan dan perkembangan dalam proses pembelajaran di sekolah.

\section{DAFTAR PUSTAKA}

Abidin, Z., Hudaya, A., \& Anjani, D. (2020). Efektivitas Pembelajaran Jarak Jauh Pada Masa Pandemi Covid-19. Research and Development Journal of Education, 1(1), 131. https://doi.org/10.30998/rdje.v1i1.7659

Ami, M. S., Susantini, E., \& Raharjo. (2012). Pengembangan Buku Saku Materi Sistem Ekskresi Manusia di SMA/MA Kelas XI. BioEdu, 1(2), 10-13.

Anita, A., Tyowati, S., \& Zuldafrial, Z. (2018). Analisis Kualitas Butir Soal Fisika 
Kelas X Sekolah Menengah Atas. Edukasi: Jurnal Pendidikan, 16(1), 35. https://doi.org/10.31571/edukasi.v16i1.780

Azadirachta, F. L., \& Sumarmi, S. (2018). Pendidikan Gizi Menggunakan Media Buku Saku Meningkatkan Pengetahuan Dan Praktik Konsumsi Sayur Dan Buah Pada Siswa Sekolah Dasar. Media Gizi Indonesia, 12(2), 107. https://doi.org/10.20473/mgi.v12i2.107-115

BSNP. (2014). Instrumen Penilaian Buku Teks Pelajaran Biologi SMA/MA. Jakarta. Departemen Pendidikan Nasional. Kementerian dan Kebudayaan. Jakarta.

Daryanto. (2012). Media Pembelajaran. Satu Nusa. Bandung

Dolong, H. M. J. (2016). Teknik analisis dalam komponen pembelajaran. Jurnal UIN Alauddin, 5(2), 293-300.

Lawshe, C. H. (1975). a Quantitative Approach To Content Validity. Personnel Psychology, 28(4), 563-575. https://doi.org/10.1111/j.1744-6570.1975.tb01393.x

Miftah, M. (2013). Fungsi, Dan Peran Media Pembelajaran Sebagai Upaya Peningkatan Kemampuan Belajar Siswa. Jurnal Kwangsan, 1(2), 95. https://doi.org/10.31800/jurnalkwangsan.v1i2.7

Pane, A., \& Darwis Dasopang, M. (2017). Belajar Dan Pembelajaran. FITRAH:Jurnal Kajian Ilmu-Ilmu Keislaman, 3(2), 333. https://doi.org/10.24952/fitrah.v3i2.945

Pramika, D. \& W. M. (2018). Buku Saku Sebagai Media Pembelajaran Matematika Ekonomi di Program Studi Pendidikan Akuntansi FKIP Universitas PGRI Palembang. Jurnal Program Studi Pendidikan Ekonomi, 6(2), 1-undefined. https://www.ojs.fkip.ummetro.ac.id/index.php/ekonomi/article/view/1685

Rafiuddin., Basri, M., \& Azis, M. (2017). Urgensi Penggunaan Media Dalam Proses Pembelajaran Bagi Guru Sekolah Dasar Wilayah II Kecamatan Sanrobone Kabupaten Takalar Provinsi Sulawesi Selatan. Prosiding TEP \& PDs, 147-157. 
Sari, Noor Linda Vitria, A. E. S. S. (2010). Studi Efektifitas Buku Saku Terhadap Skor Pengetahuan Penyakit Menular Seksual Pada Siswa SMA Negeri Banyumas. Jurnal Ilmiah Kebidanan, 1(1), 28-36.

Setyono, Y. A., Sukarmin, \& Daru, W. (2013). Pengembangan Media Pembelajaran Fisika Ditinjau Dari Motivasi Belajar. Jurnal Pendidikan Fisika, 1(1), 118-126.

Soenardihardjo, B. P. (2017). Teratologi Pada Hewan dan Ternak. Airlangga University Press. Surabaya.

Sukroyanti, B. A. (2016). Pengaruh Penggunaan Pocket Book Siswa Dengan Teknik Evaluasi Media Puzzle Ceria Terhadap Sikap Ilmiah Siswa. Lensa: Jurnal Kependidikan Fisika, 4(2), 46. https://doi.org/10.33394/j-1kf.v4i2.82

Suryanda, A., Azrai, E. P., \& Julita, A. (2019). Expert Validation on The Development Biology Pocketbook Based on Mind Map ( BIOMAP ). Biodik: Jurnal Ilmiah Pendidikan Biologi, 5(3), 197-214.

Tafonao, T. (2018). Peranan Media Pembelajaran Dalam Meningkatkan Minat Belajar Mahasiswa. Jurnal Komunikasi Pendidikan, 2(2), 103. https://doi.org/10.32585/jkp.v2i2.113

Thiagarajan, Sivasailam, \& Others. (1976). Instructional development for training teachers of exceptional children: A sourcebook. Journal of School Psychology, 14(1), 75. https://doi.org/10.1016/0022-4405(76)90066-2

Trisianawati, E., Djudin, T., \& Katihada, T. (2017). Penyediaan Bahan Bacaan Berupa Buku Saku Untuk Meningkatkan Hasil Belajar Siswa SMP Negeri 5 Monterado. Jurnal Pendidikan Informatika Dan Sains, 6(2), 219-229.

Windayani, W., Kasrina, K., \& Ansori, I. (2018). Pengembangan Buku Saku Berdasarkan Hasil Eksplorasi Tanaman Obat Suku. Diklabio: Jurnal Pendidikan Dan Pembelajaran Biologi, 2(1), 51-57. https://doi.org/10.33369/diklabio.2.1.5157 
Zuhra, F., Hasan, M., \& Safitri, R. (2017). Model Pembelajaran Learning Cyccle 7E Berbantuan Buku Saku terhadap Hasil Belajar Siswa SMA. Pendidikan Sains Indonesia, 05(01), 134-139. 